\title{
ЕЩЕ РАЗ ОБ ОТКРЫТИИ И ИССЛЕДОВАНИИ ПЕТРОГЛИФОВ ГОЛОЦЕНОВОГО ПЕРИОДА ГРОТА ЭМБА (ТОЛЕУБУЛАК) В МУГАЛЖАР
}

\section{(C) 2020 г. Жакен Кожахметович Таймагамбетов ${ }^{1}$}

\author{
${ }^{1}$ доктор исторических наук, профессор, академик НАН РК, главный научный \\ сотрудник, отдел археологии и этнографии, Национальный музей РК, \\ г. Нур-Султан, Казахстан. E-mail: zhaken.taimagambetov@gmail.com
}

Аннотация. В статье затрагиваются вопросы об авторстве, истории открытия гротаЭмба(Толеубулак), атакжеприводятсяданныеомногочисленныхпалеолитических стоянках и местонахождениях региона, обозначены перспективы дальнейших исследований археологических памятников. Основная цель археологической экспедиции Института археологии им. А. Х. Маргулана с участием заинтересованных специалистов управления культуры и историко-краеведческого музея Актюбинской области, Национального музея РК в 2020 г. заключалась в повторном обследовании грота Эмба (Толеубулак) и его окрестностей, разработке плана и включения наиболее ярких памятников археологии в туристические маршруты в рамках Государственной программы «Тұган жер». В статье приводятся новые сведения о результатах исследования памятника в 2020 г. экспедиция

Ключевые слова: археология, палеолит, грот, местонахождение, петроглифы,

\section{МҰҒАЛЖАРДАҒЫ ЕМБІ (ТӨЛЕУБҰЛАҚ) ҮНГІРІНДЕГІ ГОЛОЦЕНДІК КЕЗЕНДЕГІ ПЕТРОГЛИФТЕРДІН АШЫЛУЫ ЖӘНЕ ЗЕРТТЕЛУІНЕ ҚАЙТА ОРАЛСАҚ}

\author{
Жакен Қожахметұлы Таймағамбетов ${ }^{1}$ \\ ${ }^{1}$ т.ғ.Д., профессор, ҚР ҰҒА академигі, ҚР ҰМ БҒҚ, Нұр-Сұлтан, Қазақстан. \\ E-mail: zhaken.taimagambetov@gmail.com
}

Аннотация. Мақалада авторлық, Ембі (Төлеубұлақ) үңгірінің ашылуы, сонымен қатар сол өңірдегі көптеген палеолиттік тұрақтар мен орналасқан жері туралы мәселелер қозғалады және археологиялық ескерткіштерді зерттеудің келешегі көрсетіледі. Ә. Х. Марғұлан атынд. Археология институтының құрамында Ақтөбе облыстық мәдениет басқармасы және тарихи-өлкетану музейінің, ҚР Ұлттық музейдің қызығушылық танытқан мамандары қатысқан археологиялық экспедициясының басты мақсаты Ембі (Төлеубұлақ) үңгірін және оның маңайын қайталап зерттеу, анағұрлым маңызды археологиялық ескерткіштерді «Туған жер» мемлекеттік бағдарламасы аясындағы туристік бағыттарға қосу және оның жоспарын дайындау болып табылады. Мақалада ескерткішті зерттеу нәтижелерінің 2020 жылғы жаңа мәліметтері беріледі.

Түйін сөздер: археология, палеолит, үңгір, орналасқан жері, петроглифтер, экспедиция 
Таймагамбетов Ж.К. Еще раз об открытии и исследовании петроглифов...

\title{
ONCE AGAIN ON DISCOVERY AND STUDY OF HOLOCENE-PERIOD PETROGLYPHS OF EMBA niche (TOLEUBULAK) in MUGALJAR
}

\author{
Zhaken K. Taimagambetov ${ }^{1}$
}

\begin{abstract}
${ }^{1}$ Doctor of Historical Sciences, Professor, Academician of the National Academy of Sciences of the Republic of Kazakhstan, Chief Researcher, National Museum of the Republic of Kazakhstan, Nur-Sultan, Kazakhstan.

E-mail: zhaken.taimagambetov@gmail.com
\end{abstract}

\begin{abstract}
The article addresses the issues of authorship, the history of the discovery of the niche of Emba (Toleubulak), as well as data on the numerous Paleolithic sites and locations of the region and outlines the prospects for further research of archaeological sites. The main objective of an archaeological expedition of A. Kh. Margulan Institute of Archaeology of with participation of the interested specialists of management of culture and the local history museum of the Aktobe region, the KR National museum, consisted in repeated inspection of a niche Emba (Toleubulak) and its vicinities, to develop the plan and to include the brightest monuments of archaeology in tourist routes, within the State program "Tugan jer". The article provides new information about the results of the study of the monument in 2020.
\end{abstract}

Keywords: archaeology, Paleolithic, niche, location, petroglyphs, expedition

\section{Введение}

В полевом сезоне 2020 г. одним из направлений Института археологии им. А. Х. Маргулана с участием Национального музея РК стало исследование памятников каменного века в Мугалжар/Мугоджары (Актюбинская обл.) и определение перспективных памятников для включения в туристический маршрут окрестностей сакрального объекта - грота Эмба (Толеубулак) по проекту «Петроглифы грота-святилища Толеубулак и его культурно-исторический округ (сакральные памятники первобытных обществ Мугалжар)». Ранее известные и вновь выявленные археологические памятники охватывают период от древнего каменного века до Нового времени.

Особо отметим, что в 1999-2001 годах в Мугалжар проводила работы совместная Казахско-Российская археологическая экспедиция Института археологии и этнографии Сибирско- го отделения РАН и КазНУ им. альФараби под руководством академика А. П. Деревянко и профессора Ж. К. Таймагамбетова по выявлению и исследованию памятников каменного века Казахстана. По сообщению местных жителей Ерболата и Медета Насеновых, проживавших в с. Родники, а в настоящее время в п. Булакты Мугалжарского района Актюбинской обл. о наличии загадочных рисунков в «пещере» около родника Толеубулак, мы, участники экспедиции, посетили указанный ими объект. Таким образом, стал известен уникальный археологический памятник грот Эмба. Так первоначально и назвали грот, поскольку экспедиция работала в верховьях реки Эмба. И впервые петроглифы в гроте Эмба 1 (Толеубулак), Эмба 2 (малый грот) и Эмба 3 (вне грота) были отрисованы и исследованы совместной экспедицией в 2000 г., результаты которой были опубликованы в сборнике итоговой сессии Института археоло- 
гии и этнографии СО РАН (г. Новосибирск) [Деревянко и др., 2001].

В связи с этим считаю необоснованным и неэтичным опубликованную статью А. Онгар и соавторов «Археологические памятники микрорайона Толеубулак-Егиндибулак (предварительные итоги работ) о том, что «... в 2000 году грот с рисунками осмотрен участниками КазахскоРоссийской экспедицией...» [Онгар и др., 2009, с. 198]. Кроме того, в этой же статье приводятся сведения об «обнаруженных» ими палеолитических стоянках и местонахождениях в районе грота и родника Толеубулак, хотя и эти памятники были впервые выявлены совместной Казахско-Российской археологической экспедицией. За три года (1999-2001) нашей экспедицией обнаружено более 100 памятников палеолита, которые получили отражение в многочисленных научных статьях и монографических изданиях, список которых считаю уместным привести полностью [Деревянко и др., 1999, c. $50-55 ; 2000$, с. $64-67 ; 2001$, c. $86-$ 93; 2001; 2003]. Поэтому вызывает глубокое недоумение то, что А. Онгар и соавторы, игнорируя известные факты, мягко говоря, использовали сведения по палеолиту Мугалжар и петроглифов грота Эмба (Толеубулак), не утруждая себя даже ссылками на давно вышедшие публикации.

Далее, в последующие годы экспедицией по изучению памятников каменного века КазНУ им. альФараби под руководством Ж. К. Таймагамбетова в Мугалжар выявлены еще сотни новых палеолитических местонахождений и стоянок, артефакты которых обработаны и переданы в историко-краеведческий музей г. Актобе, музей Института археологии им. А. Х. Маргулана и музей палеоли- та КазНУ им. аль-Фараби. Результаты исследований были использованы в диссертации Т. Б. Мамирова, представленной на соискание ученой степени кандидата исторических наук, и впоследствии опубликованы в нашей совместной статье и монографии [Таймагамбетов, Мамиров, 2010; 2012]. Грот Эмба 1 (Толеубулак) и Эмба 2 (малый грот) дополнительно исследовались нами в 2008 г. и полученные результаты получили отражение в совместной монографии автора данной статьи с Н. Ю. Сойкиной [Таймагамбетов, Сойкина, 2016].

Характеристика материала

Отметим, что в Казахстане голоценовых памятников древнего искусства известны единицы: грот Драверта [Драверт, 1930], грот Акбаур [Самашев, 2006], урочище Ак Бидаик [Мерц, 2002] и грот Арасан [Таймагамбетов и др., 2009].

В указанных памятниках отражаются отголоски палеолитической живописи. На их примере можно сказать, что «неолитическая революция» приводит к окончательному исчезновению палеолитических традиций в искусстве, а именно живописи и переходу к скупой выразительности петроглифов. Живопись постепенно утрачивает значение и в целом, в период мезолитаэнеолита, повсеместно исчезают последние примеры раскрашивания стен пещер и гротов.

В этом отношении интерес представляют рисунки грота Эмба (Толеубулак) (рис. 1-3).

Благодаря исследованиям казахстанских специалистов по наскальному искусству М. К. Кадырбаева, А. Н. Марьяшева, 3. Самашева, В. А. Новоженова, А. Е. Рогожинского и других, в Казахстане подняты многие проблемы в этом направлении, но, 
Таймагамбетов Ж.К. Еще раз об открытии и исследовании петроглифов...

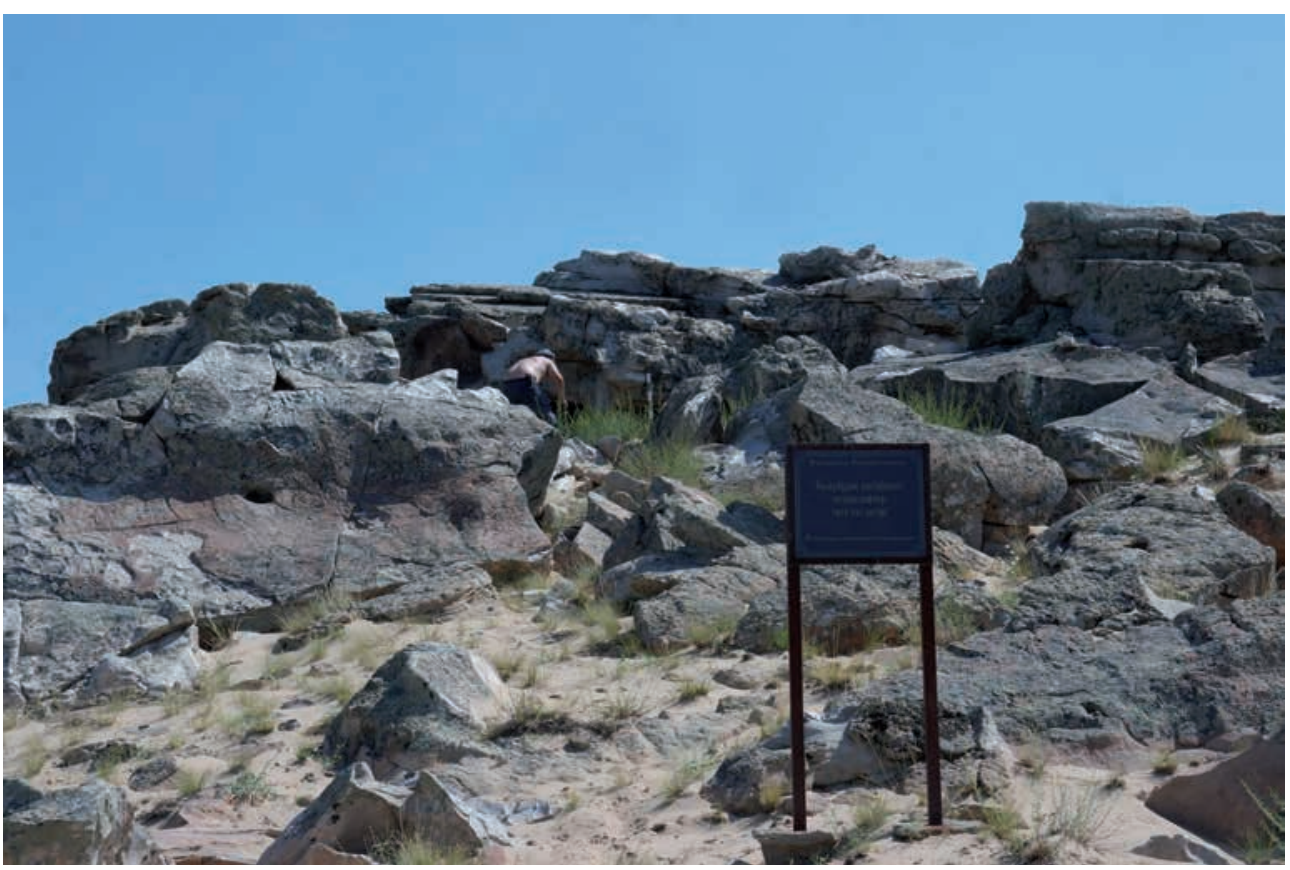

Рис. 1. Общий вид на грот Эмба (Толеубулак). Фото Ж.К. Таймагамбетова Fig. 1. Emba niche (Toleubulak). Photo by Zh.K. Taimagambetov

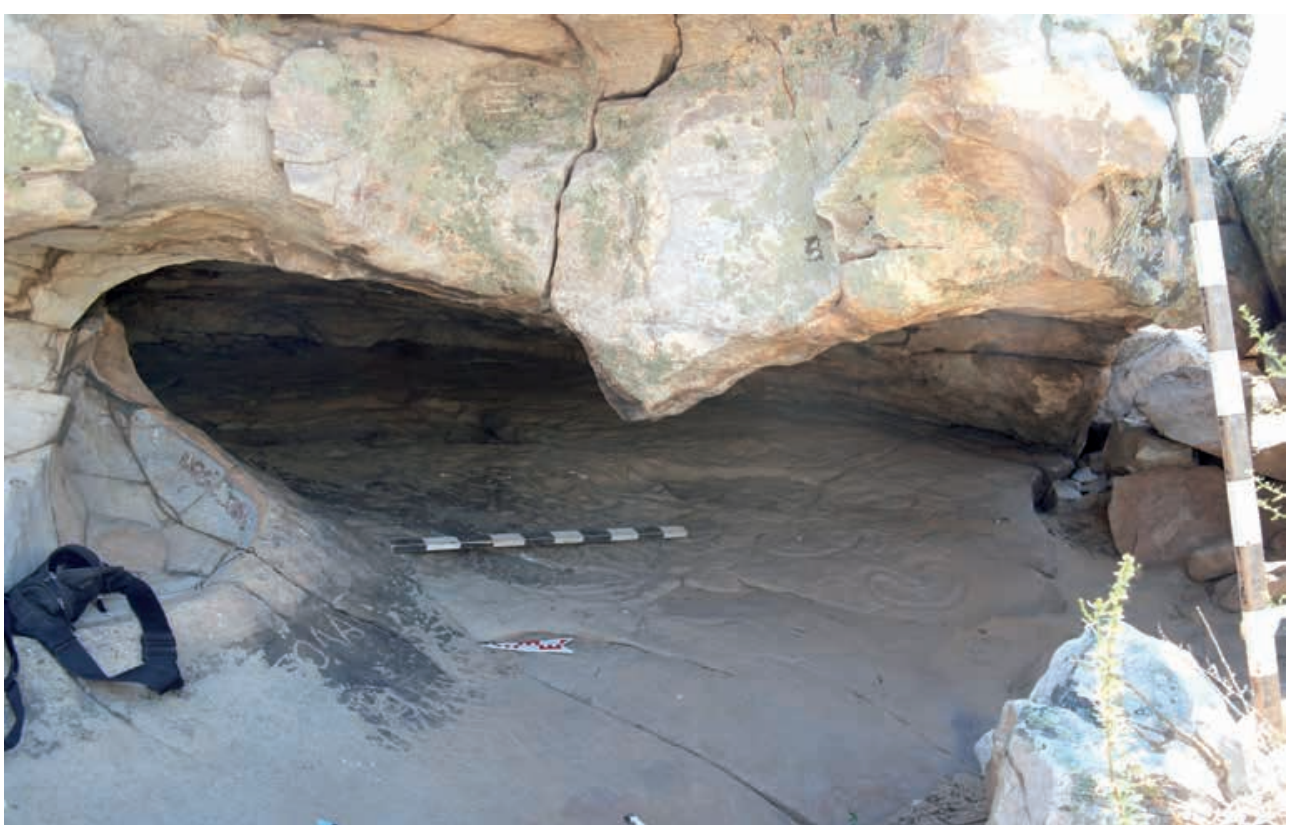

Рис. 2. Рисунки на полу большого грота. Фото Ж.К. Таймагамбетова

Fig. 2. The drawings on the floor of a large niche. Photo by Zh.K. Taimagambetov 


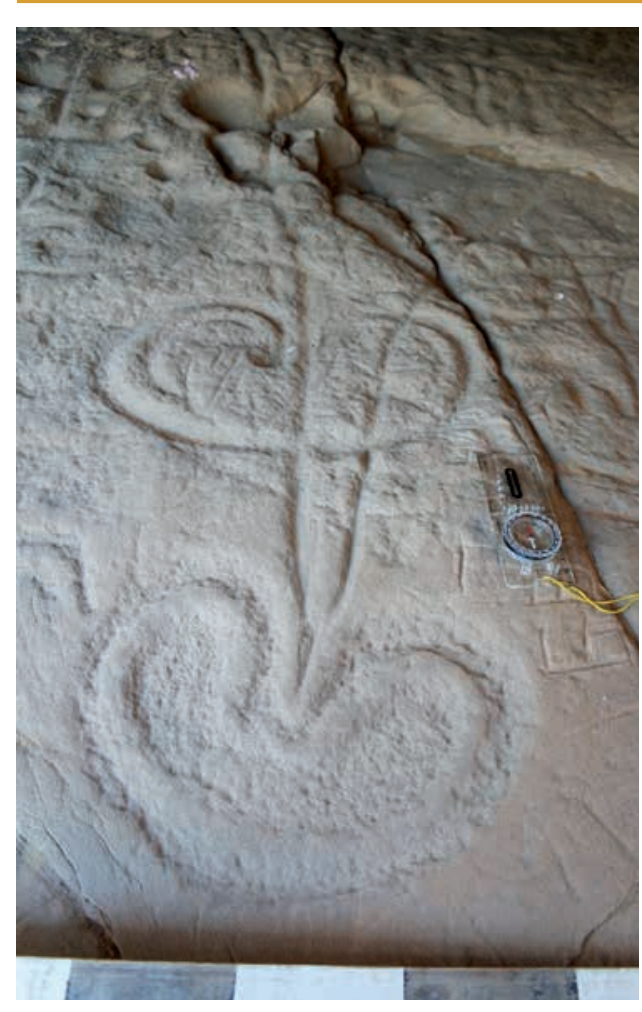

Рис. 3. Рисунки в нижней части большого грота. Фото Ж.К. Таймагамбетова

Fig. 3. The drawings at the lower part of the large niche. Photo by Zh.K. Taimagambetov

самое главное, ими успешно выделены хронологические группы изображений эпохи энеолита, бронзы, железа и средневековья.

Каковы же истоки появления петроглифов в гроте Эмба (Толеубулак) и его окрестностях, которые представляют собой ценнейший источник для понимания духовной жизни и культуры древнего человека, его мировоззрения? Ведь представления о священных пещерах и гротах как о местах, где отправляли культ поклонения древним охотничьим богам, плодородия, были известны еще со времени верхнего палеолита. С какой целью создавались гравюры на скалах Мугалжар? В этом отношении важ- ны этнографические параллели. Как указывал А. А. Формозов, «исследователь должен решать четыре задачи: определить дату и разобраться в технике исполнения рисунков, оценить их как произведения искусства и постичь их тайный смысл» [Формозов, 1966, с. 74].

Гравировки в гроте Эмба 1 и 2 (Толеубулак) и его окрестностях уникальны и аналогов на территории Казахстана им пока нет. Наличие местонахождений и стоянок ашельского времени, неолита, памятников эпохи бронзы, курганов эпохи железа и средневековья свидетельствует о том, что грот Эмба (Толеубулак) был пристанищем для человека на протяжении тысячелетий. Однозначно, рисунки создавались не для развлечения. Это было частью тайных, религиозных церемоний, без которых человек не мыслил благополучия и роста населения своей общины. Это было ритуальное магическое действие, необходимое для продолжения рода, жизни. Это единственный на сегодня в Казахстане грот с самыми ранними древними рисунками - петроглифами, имеющими сакральный смысл.

Возникновение грота Эмба (Толеубулак) связано, вероятно, с отвердением песчаных масс вследствие высокого содержания железосодержащих минералов. В результате водной и воздушной эрозии массив песчаника осел и постепенно раскололся на массивные глыбы, о чем свидетельствуют беспорядочно рассеянные крупные блоки камня вокруг грота. Сооружение грота природного происхождения размерами $3 \times 4$ м и труднодоступность, скрытость его от постороннего взгляда свидетельствует о сакральности объекта.

На протяжении длительного времени грот природного образова- 
Таймагамбетов Ж.К. Еще раз об открытии и исследовании петроглифов...

ния Эмба (Толеубулак) был местом отправления культовых ритуалов, своеобразным храмом древних насельников Мугалжар. И это понятно, в контактной зоне между степью и горами изолированно возвышающееся нагромождение из кварцитопесчаника с гротом привлекало древних людей. Обветренные тысячелетиями и покрытые местами зеленоваторыжим лишайником камни и скалы и сегодня местами снаружи содержат одиночные «фаллические» знаки. Однако основные рисунки нанесены на пол внутри грота. Вначале создается впечатление, что рисунки нанесены хаотично, но при внимательном знакомстве можно выделить три пласта «разновременных», судя по технике нанесения и сюжету, петроглифов. В самом верху - линии и штрихи, линейно-штриховые композиции, ряд резных параллельных и субпараллельных линий, серединв заполнена своеобразными овальными незамкнутыми фигурами с двумя линиями, проходящими через них, и в самом внизу - «чашевидные» углубления. Некоторые рисунки основного грота посвящены знакам и символам и содержат изображения, относящиеся к голоцену. На наш взгляд, в этом одна из уникальностей памятника - здесь, видимо, пересекаются три разные исторические эпохи - мезолит, неолит и энеолит.

Рисунки нанесены на мягкую поверхность твердым предметом, скорее всего небольшими камнями твердых пород, которые легко оставляют следы на кварцитопесчанике, это так называемая - углубленная техника. Благодаря этому обстоятельству, гравюры и сохранились до наших дней. Рисунки в святилище посвящены знакам и символам. Техника выполнения резная с последующей пришлифовкой некоторых наиболее углубленных деталей «чашеобразных» углублений. Некоторые гравировки очень схожи между собой, создается впечатление, что они выполнены одним человеком. Гравировки следует трактовать как символическое изображение «мужского» и «женского начала». Отметим, что фаллические и «бобовидные» изображения имеют между собой промежуточные формы, что указывает на единство этих двух образов, мужского и женского [Таймагамбетов, 2004].

Культ плодородия известен еще с эпохи палеолита и долгое время не утрачивает свою значимость. В палеолите знаки мужского и женского пола представлены значительным числом произведений искусства. Это было то время, когда обеспечение плодородия было одной из основных забот племени. Низкий уровень рождаемости и высокий - смертности среди человеческих популяций приводил к увеличению значения такого культа. Поэтому роль культа плодородия трудно переоценить и в этом отношении гроты Эмба 1 и 2 использовались в качестве святилищ, посвященных божествам плодородия, в которых проводились религиозные обряды. Гравировка применялась для создания своеобразных «храмов» древнего человека, посвященных божеству плодородия.

Однако своеобразие рисунков основного грота делает трудным попытку интерпретации, а наличие линейно-штриховых композиций усложняет раскрытие сокрытых в них сюжетов. В этом отношении доминируют рисунки малого грота, которые и состоят, в основном, из линейноштриховых композиций.

Символические изображения наполнены глубоким смысловым со- 
держанием. По силе выразительности, технике нанесения они могут быть сравнимы, к примеру, лишь с гротом Каменная могила, что в Приазовье, рисунки датируются эпохой мезолита (10-12 тысяч лет назад) [Мацкевой, 1977].

Акцентируем внимание на изображении символов грота. Помимо памятника Каменная могила (Приазовье), символы достаточно известны среди изображений Хойт-Ценкер агуй, Аржан-хада (Монголия) [Окладников, 1972].

Линейно-штриховые композиции присутствуют и в живописях палеолитического времени, так и в последующие периоды, но уже на наскальных рисунках. Они встречаются во многих памятниках Европы и Азии, что свидетельствует о схожести пути развития и сложения древнейшего мифа [Новгородова, 1984]. Наиболее часто встречаются знаковые изображения, символы мужского и женского начала: знака копыта, овалы, треугольники, различные круги - женское начало и мужские - линии, стрелки, фаллические изображения. Эти и многие другие знаки являются характерными для памятников мезолита, и они присутствуют в гроте Эмба (Толеубулак).

Наличие рисунка лошади около малого грота Эмба предполагает датировать петроглифы ранней порой голоценового периода. Она очень схожа с лошадью из палеолитической пещеры Каповая, что на Урале. Разница в том, что в первом случае рисунок выбит, а во втором - нанесен охрой [Бадер, 1965].

Мы можем говорить о том, что рисунки грота Эмба и его окрестностей являются памятником раннеголоценового времени и последующих эпох. В Мугалжар зарождалось новое искусство, отличное от палеолитической пещерной живописи.

\section{Bblводbl}

Таким образом, наличие на территории Казахстана памятников изобразительного искусства голоценового периода, в том числе и Эмба (Толеубулак) в Мугалжар, говорит о достаточно раннем развитии художественной традиции.

Археологические находки в виде многочисленных каменных орудий свидетельствуют о заселении Мугалжар человеком еще в ашельское время, о своеобразии развития его культуры в палеолите и о местных традициях искусства, развивашихся в раннем голоцене.

К сожалению, по происшествии 20 лет со дня первоначального научного исследования, мы можем отметить, что идет постепенное разрушение петроглифов большого грота и особенно малого грота, где «выпала» целая скала с рисунками с намеренным уничтожением в результате вмешательства человека.

Нужно огородить вход в гроты решетками, сделать недоступным для проникновения вандалов и животных. Это единственный уникальный объект с ранними рисунками. Это место издавно привлекало человека, начиная от эпохи палеолита, о чем свидетельствуют сотни местонахождений и стоянок первобытного человека, памятники эпохи бронзы, железа и средневековья. Кроме того, рядом с гротом Эмба (Толеубулак) имеется целебное озеро Туздыколь, площадью более 50 га, родниковая вода и озеро Толеубулак, где можно развивать рыбное хозяйство. Мало кто знает, что именно здесь создавалась мугалжарская 
Таймагамбетов Ж.К. Еще раз об открытии и исследовании петроглифов...

порода лошадей, а в селе сохранился в первозданном виде удивительный памятник архитектуры $50-x$ годов прошлого столетия - дом культуры, который при необходимости можно переоборудовать под гостиницу.
Нужно сейчас, пока еще не поздно, придать микрорайону «Толеубулак» статус природного и историкоархеологического заповедника, включив памятники в туристические маршруты.

\section{ЛИТЕРАТУРА}

1. Бадер О.Н. Каповая пещера. Палеолитическая живопись. М.: Наука, 1965. $44 \mathrm{c}$.

2. Деревянко А.П., Петрин В.Т., Гладышев С.А., Таймагамбетов Ж.К., Ламин В.В., Искаков Г.Т., Абсадык Ж. Открытие петроглифов в верховьях р. Эмба в Мугоджарских горах // Проблемы археологии, этнографии, антропологии Сибири и сопредельных территорий: м-лы Годовой сессии ИАЭт СО РАН (декабрь 2001 г.). Новосибирск: ИАЭт CO PAH, 2001. T. VII. C. 100-103.

3. Деревянко А.П., Петрин В.Т., Гладышев С.А., Зенин А.Н., Таймагамбетов Ж.К., Искаков Г.Т. Палеолитические комплексы поверхностного залегания Мугоджарских гор // Проблемы археологии, этнографии, антропологии Сибири и сопредельных территорий: м-лы VII Годовой итоговой сессии ИАЭт СО РАН (декабрь 1999 г.). Новосибирск: ИАЭт СО РАН, 1999. Т. V. С. 50-55.

4. Деревянко А.П., Петрин В.Т., Зенин А.Н., Гладышев С.А., Искаков Г.Т. Исследования палеолита в Мугоджарах (Северо-западный Казахстан) // Проблемы археологии, этнографии, антропологии Сибири и сопредельных территорий: м-лы Годовой юбилейной сессии ИАЭт СО РАН (декабрь 2000 г.). Новосибирск: ИАЭт СО PAH, 2000. T. VI. C. 64-67.

5. Деревянко А.П., Петрин В.Т., Гладышев С.А., Таймагамбетов Ж.К., Абсадык Ж., Искаков Г.Т. Итоги изучения палеолита Мугоджарских гор (Актюбинская область, Республика Казахстан) // Проблемы археологии, этнографии, антропологии Сибири и сопредельных территорий: м-лы Годовой сессии ИАЭт СО РАН (декабрь 2001 г.). Новосибирск: ИАЭт СО РАН, 2001. Т. VII. С. 86-93.

6. Деревянко А.П., Петрин В.Т., Гладыпев С.А., Зенин А.Н., Таймагамбетов Ж.К. Ашельские комплексы Мугоджарских гор (Северо-Западная Азия). Новосибирск: ИАЭТ СО РАН, 2001. 136 c.

7. Деревянко А.П., Петрин В.Т., Зенин А.Н., Таймагамбетов Ж.К., Гладымев С.А., Цыбанков А.А., Славинский В.С. Исследования Российско-Казахстанской экспедиции в Казахстане (1998-2001 гг.). Новосибирск: ИАЭт СО РАН, 2003. 183 с.

8. Драверт П. Грот с писаницей на озере Джасыбай в окрестностях Баян-Аула // Известия Западно-Сибирского отдела РГО. 1930. Вып. VII. С. 231-234.

9. Мацкевой Л.Г. Мезолит и неолит восточного Крыма. Киев: Наукова думка, 1977. $180 \mathrm{c}$

10. Мери В.К. Наскальные рисунки края Кереку-Баян. Павлодар: ТОО «Эверо», 2002. $112 \mathrm{c}$.

11. Новгородова Э.А. Мир петроглифов Монголии. М.: Наука, 1984. 168 с.

12. Окладников А.П. Центрально-Азиатский очаг первобытного искусства. Новосибирск: Наука, 1972. 75 с.

13. Онгар А., Нурпеисов М., Киясбек Г., Логвин А., ЖетписбайН. Археологические памятники микрорайона Толеубулак-Егиндибулак (предварительные итоги работ) // Вопросы истории и археологии Западного Казахстана. 2009. № 1. С. 197-213. 
14. Самашев 3. Петроглифы Казахстана. Алматы: Өнер, 2006. 200 с.

15. Таймагамбетов Ж.К. Музей палеолита Казахстана в свете новейших археологических открытий // Труды ЦГМ РК. 2004. Т. 1. С. 54-59.

16. Таймагамбетов Ж.К., Байпаков К.М., Марьямев А.Н. Находки древних писаниц в гроте Арасан на реке Биен // Медный всадник. 2009. № 1 (4). С. 31-32.

17. Таймагамбетов Ж.К., Мамиров Т.Б. Новые палеолитические памятники в Мугалжарах // Кадырбаевские чтения - 2010: м-лы II Междунар. научн. конф. Актобе: Актюбинский областной центр истории, этнографии и археологии, 2010. С. 33-37.

18. Таймагамбетов Ж.К., Мамиров Т.Б. Палеолит Арало-Каспийского региона. Алматы: «Қазақ университеті», 2012. 253 с.

19. Таймагамбетов Ж.К., Сойкина Н.Ю. Искусство палеолита Евразии. Алматы: «Хантәңірі» 2016. $231 \mathrm{c}$.

20. Формозов А.А. Памятники первобытного искусства. М.: Наука, 1966. 126 с.

\section{REFERENCES}

1. Bader, O. N. 1965. Kapovaya peshchera. Paleoliticheskaya zhivopis (Kapovaya cave. Paleolithic painting). Moscow: "Nauka" Publ. (in Russian).

2. Derevyanko, A. P., Petrin, V. T., Gladyshev, S. A., Taimagambetov, Zh. K., Lamin, V. V., Iskakov, G. T., Absadyk, Zh. 2001. In Problemy arheologii, etnografii, antropologii Sibiri i sopredelnyh territorij (Problems of archeology, ethnography, anthropology of Siberia and adjacent territories), VII. Novosibirsk: IAEt SO RAN, 100-103 (in Russian).

3. Derevyanko, A. P., Petrin, V. T., Gladyshev, S. A., Zenin, A. N., Taimagambetov, Zh. K., Iskakov, G. T. 1999. In Problemy arheologii, etnografi, antropologii Sibiri $i$ sopredel'nyh territorij (Problems of archeology, ethnography, anthropology of Siberia and adjacent territories), V. Novosibirsk: IAEt SO RAN, 50-55 (in Russian).

4. Derevyanko, A. P., Petrin, V. T., Zenin, A. N., Gladyshev, S. A., Iskakov, G. T. 2000. In Problemy arheologii, etnografii, antropologii Sibiri i sopredel'nyh territorij (Problems of archeology, ethnography, anthropology of Siberia and adjacent territories), VI. Novosibirsk: IAEt SO RAN, 64-67 (in Russian).

5. Derevyanko, A. P., Petrin, V. T., Gladyshev, S. A., Taimagambetov, Zh. K., Absadyk, Zh., Iskakov, G. T. 2001. Problemy arheologii, etnografii, antropologii Sibiri $i$ sopredel'nyh territorij (Problems of archeology, ethnography, anthropology of Siberia and adjacent territories), VII. Novosibirsk: IAEt SO RAN, 86-93 (in Russian).

6. Derevyanko, A. P., Petrin, V.T., Gladyshev, S.A., Zenin,A. N., Taimagambetov, Zh. K. 2001. Ashelskie kompleksy Mugodzharskih gor (Severo-Zapadnaya Aziya) (Asheulian complexes of the Mugodzhar mountains (North-West Asia)). Novosibirsk: IAEt SO RAN (in Russian).

7. Derevyanko, A. P., Petrin, V. T., Zenin, A. N., Taimagambetov, Zh. K., Gladyshev, S. A., Tsybankov, A. A., Slavinskij, V. S. 2003. Issledovaniya Rossijsko-Kazahstanskoj ekspedicii v Kazahstane (1998-2001 gg.) (Research of the Russian-Kazakh expedition in Kazakhstan (1998-2001)). Novosibirsk: IAEt SO RAN (in Russian).

8. Dravert, P. 1930. In Izvestiya Zapadno-Sibirskogo otdela RGO (News of the West Siberian Department of the Russian Geographical Society), VII, 231-234 (in Russian).

9. Mackevoj, L. G. 1977. Mezolit i neolit vostochnogo Kryma (Mesolithic and Neolithic of eastern Crimea). Kiev: "Naukova dumka" Publ. (in Russian).

10. Merc, V. K. 2002. Naskalnye risunki kraya Kereku-Bayan (Rock paintings of the Kereku-Bayan region). Pavlodar: "Evero" Publ. (in Russian).

11. Novgorodova, E. A. 1984. Mir petroglifov Mongolii (The world of petroglyphs of Mongolia). Moscow: "Nauka" (in Russian).

12. Okladnikov, A. P. 1972. Centralno-Aziatskij ochag pervobytnogo iskusstva (Central Asian cradle of primitive art). Novosibirsk: "Nauka" Publ. (in Russian). 
Таймагамбетов Ж.К. Еще раз об открытии и исследовании петроглифов...

13. Ongar, A., Nurpeisov, M., Kiyasbek, G., Logvin, A., Jetpisbaj, N. 2009. In: Voprosy istorii i arheologii Zapadnogo Kazahstana (Questions of history and archeology of Western Kazakhstan), 1, 197-213 (in Russian).

14. Samashev, Z. 2006. Petroglify Kazahstana (Petroglyphs of Kazakhstan). Almaty: "Oner" Publ. (in Russian).

15. Taimagambetov, Zh. K. 2004. In Trudy CGM RK (Proceedings of the Central State museum of the Republic of Kazakhstan)), 1, 54-59 (in Russian).

16. Taimagambetov, Zh. K., Baipakov, K. M., Maryashev, A. N. 2009. In: Mednyj vsadnik, 1 (4), 31-32 (in Russian).

17. Taimagambetov, Zh. K., Mamirov, T. B. 2010. In: Kadyrbaevskie chteniya - 2010 (Kadyrbayev readings - 2020). Aktobe: Aktyubinskij oblastnoj centr istorii, etnografii i arheologii, 33-37 (in Russian).

18. Taimagambetov, Zh. K., Mamirov, T. B. 2012. Paleolit Aralo-Kaspijskogo regiona (Paleolit of the Aral-Caspian region). Almaty: "Kazakh University" (in Russian).

19. Taimagambetov, Zh. K., Sojkina, N. Yu. 2016. Iskusstvo paleolita Evrazii (Paleolithic art of Eurasia). Almaty: "Hantaniri" Publ. (in Russian).

20. Formozov, A. A. 1966. Pamyatniki pervobytnogo iskusstva (Monuments of primitive art). Moscow: "Nauka” Publ. (in Russian).

Мүдделер қақтығысы туралы ақпаратты ашу. Автор мүдделер қақтығысының жоқтығын мәлімдейді. / Раскрытие информации о конфликте интересов. Автор заявляет об отсутствии конфликта интересов. / Disclosure of conflict of interest information. The author claim no conflict of interest.

Мақала туралы ақпарат / Информация о статье / Information about the article Редакцияға түсті / Поступила в редакцию / Entered the editorial office: 02.08.2020. Рецензенттер мақұлдаған / Одобрено рецензентами / Approved by reviewers: 10.08.2020. Жариялауға қабылданды / Принята к публикации / Accepted for publication: 20.08.2020. 